\title{
Estimation of genetic parameters and selection of high-yielding, upright common bean lines with slow seed-coat darkening
}

\author{
R.C. Alvares ${ }^{1}$, F.C. Silva ${ }^{1}$, L.C. Melo ${ }^{2}$, P.G.S. Melo ${ }^{1}$ and H.S. Pereira ${ }^{2}$ \\ ${ }^{1}$ Universidade Federal de Goiás, Goiânia, GO, Brasil \\ ${ }^{2}$ Embrapa Arroz e Feijão, Santo Antônio de Goiás, GO, Brasil \\ Corresponding author: H.S. Pereira \\ E-mail: helton.pereira@embrapa.br
}

Genet. Mol. Res. 15 (4): gmr15049081

Received August 16, 2016

Accepted September 19, 2016

Published November 21, 2016

DOI http://dx.doi.org/10.4238/gmr15049081

Copyright $(2016$ The Authors. This is an open-access article distributed under the terms of the Creative Commons Attribution ShareAlike (CC BY-SA) 4.0 License.

\begin{abstract}
Slow seed coat darkening is desirable in common bean cultivars and genetic parameters are important to define breeding strategies. The aims of this study were to estimate genetic parameters for plant architecture, grain yield, grain size, and seed-coat darkening in common bean; identify any genetic association among these traits; and select lines that associate desirable phenotypes for these traits. Three experiments were set up in the winter 2012 growing season, in Santo Antônio de Goiás and Brasília, Brazil, including 220 lines obtained from four segregating populations and five parents. A triple lattice 15 x 15 experimental design was used. The traits evaluated were plant architecture, grain yield, grain size, and seed-coat darkening. Analyses of variance were carried out and genetic parameters such as heritability, gain expected from selection, and correlations, were estimated. For selection of superior lines, a "weight-free and parameter-free" index was used. The estimates of genetic variance, heritability, and gain expected
\end{abstract}


from selection were high, indicating good possibility for success in selection of the four traits. The genotype $\mathrm{x}$ environment interaction was proportionally more important for yield than for the other traits. There was no strong genetic correlation observed among the four traits, which indicates the possibility of selection of superior lines with many traits. Considering simultaneous selection, it was not possible to join high genetic gains for the four traits. Forty-four lines that combined high yield, more upright plant architecture, slow darkening grains, and commercial grade size were selected.

Key words: Phaseolus vulgaris; Heritability; Gain from selection; Simultaneous selection

\section{INTRODUCTION}

Common bean (Phaseolus vulgaris L.) is one of the most important crops in Brazil, which is among the largest producers and consumers of beans worldwide (FAO, 2016). Among the diverse commercial groups of common bean, the carioca group stands out as the most preferred and consumed bean type in the country, representing $70 \%$ of the Brazilian consumer market (Pereira et al., 2012). To achieve maximum commercial value, the grains should have a standard size of 25 to $27 \mathrm{~g}$ per 100 seeds, a light straw- or cream-colored background, and light brown stripes. Any change in this standard results in devaluation of the grains by the packaging industries because consumers associate a darker color with greater age and consequent difficulty in cooking (Junk-Knievel et al., 2008).

Darkening of grains has been attributed to harvest conditions, which are subject to variations in temperature, moisture, and incidence of light (Junk-Knievel et al., 2007), as well as time in storage and storage conditions (Couto et al., 2010; Siqueira et al., 2014). For these reasons, the storage period for common bean is quite low, which obliges the producer to bring the product to the market rapidly, regardless of the price. In regard to genetic control of seedcoat darkening, there are reports in the literature indicating monogenic or oligogenic control (Junk-Knievel et al., 2008; Elsadr et al., 2011; Silva et al., 2008, 2014). Some of these studies indicate the possibility of obtaining and selecting promising lines.

Among the few carioca type common bean cultivars that exhibit slow darkening of grains, BRSMG Madrepérola stands out (Carneiro et al., 2012). However, this cultivar has prostrate plant architecture, which is undesirable because it implies high losses during mechanized harvest, as well as a reduction in grain quality since the pods are in contact with the ground at the time of harvest. In contrast, there are several carioca bean cultivars with upright architecture, such as BRS Sublime, BRS Estilo, and BRS Cometa; however, all of these have normal darkening of grains. The possibility of selection for upright plant architecture in common bean plants has been previously explored (Silva et al., 2009). Silva et al. (2009) concluded that it is possible to select plants with upright architecture and high yield, even though the correlation between these traits is negative and of low magnitude.

Increased grain yield is sought in all plant breeding programs for species of commercial interest. For common bean with carioca grains, recent studies have shown genetic gains of around $0.7 \%$ a year (Faria et al., 2013). This is reflected in an increase in mean Brazilian yield for the crop, from $794 \mathrm{~kg} / \mathrm{ha}$ in 1997 to $1400 \mathrm{~kg} / \mathrm{ha}$ in 2013 (Feijão, 2015). Thus, breeding

Genetics and Molecular Research 15 (4): gmr15049081 
programs direct their efforts towards obtaining promising segregating populations with the aim of selecting plants that include not only high yield but also upright architecture and slow darkening of grains in the same genotype. Obtaining estimates of genetic and phenotypic parameters makes it possible to know the potential of segregating populations and study the association between target traits, allowing the use of selection indices to make the process more efficient (Martins et al., 2016). The aims of the present study were to estimate genetic and phenotypic parameters for seed-coat darkening, grain yield, grain size, and plant architecture in common bean; identify any genetic association among these traits; and select lines that join desirable phenotypes for these traits.

\section{MATERIAL AND METHODS}

Initially, four segregating populations were selected to obtain improved lines, based on evaluations made by Silva (2012). In this study, we evaluated 20 segregating populations obtained from crosses in a partial diallel arrangement between two common bean cultivars with carioca type grain and slow seed-coat darkening (group 1) and another 10 cultivars with normal seed-coat darkening (group 2). The four segregating populations were selected considering the potential for slow seed-coat darkening, upright architecture, and high grain yield (BRSMG Madrepérola x BRS Estilo, BRSMG Madrepérola x BRS Cometa, BRSMG Madrepérola x BRS Notável, and BRSMG Madrepérola x BRS Sublime).

The four segregating populations in the $\mathrm{F}_{5}$ generation were sown in Santo Antônio de Goiás in the 2011 winter growing season, to obtain progenies. We randomly harvested 100 plants from each population, which gave rise to the $\mathrm{F}_{5: 6}$ lines. The $\mathrm{F}_{5: 6}$ lines were sown in the 2011 rainy growing season for multiplication of seeds. After harvest, 55 lines from each population were chosen at random. With these lines, three experiments were set up, composed of 220 lines and five parents (BRSMG Madrepérola, BRS Estilo, BRS Sublime, BRS Notável, and BRS Cometa) in a $15 \times 15$ lattice experimental design with plots of two 3-m rows; two experiments had three replications and one had two replications. One experiment was carried out in Santo Antônio de Goiás and the other two in Brasília, on different sowing dates. The three experiments were set up in the 2012 winter crop season. Base fertilization was carried out according to that recommended from soil analysis, and the other crop treatments followed the normal recommendations for the common bean crop, except for disease control, which was not performed.

The traits evaluated were plant architecture, grain yield, grain size, and seed-coat darkening. Plant architecture was measured using the scoring scale proposed by Melo (2009), in which score 1 refers to totally upright plants and score 9 refers to totally prostrate plants. Grain yield was obtained in $\mathrm{g} / \mathrm{plot}$, harvesting all the plants from the two rows, with later conversion to $\mathrm{kg} / \mathrm{ha}$. A 100-grain sample was collected at random from each plot for later weighing and determination of grain size, which is indicated by 100 -grain weight. These samples were subsequently stored in transparent plastic bags under ambient temperature and moisture conditions and evaluated for seed-coat darkening at 90 days after harvest. For that purpose, the scoring scale proposed by Silva et al. (2008) was adopted, which ranges from 1 (very light-colored background) to 5 (very dark-colored background).

Individual analyses of variance were performed for each experiment and trait, as well as combined analyses of variance, considering the random effect of lines and fixed effect of environments. The breakdown of the effect of the treatments, and genotype $\mathrm{x}$ environment

Genetics and Molecular Research 15 (4): gmr15049081 
interaction in the sources due to the four populations and interactions were realized. Components of variance were estimated, including genetic variance, phenotypic variance, variance of the line $\mathrm{x}$ environment interaction, and genetic and phenotypic parameters, such as heritability $\left(h^{2}\right)$ and gain expected from direct selection for each trait and from simultaneous selection of traits (Ramalho et al., 1993; 2012; Vencovsky and Barriga, 1992).

Gain expected from selection of the best lines for each trait was estimated for a selection intensity of $20 \%$ for each population and considering the combined populations; that is, in all, the 11 best lines per population and the 44 best lines were selected, regardless of population of origin. For simultaneous selection of traits, the "weight-free and parameter-free" selection index was applied (Elston, 1963). The choice of the index is based on the minimum (or maximum) values established for the traits that are the objects of selection, especially seed-coat darkening, which was the trait of greatest importance in this study. For yield, the minimum value established was the mean value of the lines, and for seed-coat darkening, the maximum score of 2.5. The lines that followed these proposed limits were pre-selected, and after that, among these, those that exhibited the best performance for plant architecture and 100 -grain weight were selected. Selection was made for each environment and for the mean of the environments. Of the 44 lines selected, regardless of the population of origin, the number of lines derived from each population was counted.

For verification of experimental precision, the coefficient of variation $(\mathrm{CV})$ was calculated, and to define the power of discrimination of the lines in each experiment, selective accuracy (SA) was estimated, as described by Resende and Duarte (2007). In addition, the phenotypic and genotypic correlation coefficients for the mean values in the combined analysis of the environments were estimated, including the grain yield, seed-coat darkening, grain size, and plant architecture traits. The phenotypic and genotypic correlations were estimated using the expressions described in Ramalho et al. (2012). Analyses were performed using Genes (Cruz, 2013) and SAS ${ }^{\circledR}$ (SAS Institute Inc., 2008).

\section{RESULTS AND DISCUSSION}

The results of the individual and combined analyses of variance indicated the presence of genetic variability among the lines for all four traits, making selection of superior lines possible. Good experimental precision was observed, as determined by the CV and good power of discrimination of the lines, estimated by SA (Table 1). The environmental effect for yield, plant architecture, and 100-grain weight was also detected (Table 1), which was commonly studied previously (Pereira et al., 2012; Moura et al., 2013). As for seed-coat darkening, no difference among the environments was detected, which can be explained by all three experiments having been carried out in the winter, without the occurrence of rain at harvest, and with very low indices of relative humidity, which contributed to making the environmental conditions uniform.

The genotype $\mathrm{x}$ environment interaction was significant for all four traits, considering all lines combined (Table 1). This has been reported in the literature for grain yield (Silva et al., 2009; Pereira et al., 2012), for 100-grain weight (Melo et al., 2004; Pereira et al., 2012; Moura et al., 2013), and for plant architecture (Moura et al., 2013). For seed-coat darkening, the presence of the genotype $\mathrm{x}$ environment interaction has been reported by some authors (Ribeiro et al., 2004; Junk-Knievel et al., 2007; Araújo et al., 2012). However, some of these results are restricted to evaluation of genotypes with normal darkening; that is, the grains

Genetics and Molecular Research 15 (4): gmr15049081 
that exhibit an evident change in seed-coat coloring during storage. The results obtained in this study indicate that lines with variability for seed-coat darkening also do not exhibit a coinciding response in the environments. Therefore, there was variation in classification of the lines in regard to darkening of grains to the extent that the crop environment is changed, which is consistent with that reported by Silva (2012) and Araújo et al. (2012). This suggests that evaluations of the lines in various environments should be carried out to ensure greater precision in selection of lines with slow seed-coat darkening.

Table 1. Summary of combined analyses of variance in three environments for grain yield ( $\mathrm{kg} / \mathrm{ha})$, seed-coat darkening (scoring scale from 1 to 5), plant architecture (scoring scale from 1 to 9), and 100-grain weight (g).

\begin{tabular}{|c|c|c|c|c|c|c|c|c|c|}
\hline \multirow[t]{2}{*}{ Source of variation } & \multirow[t]{2}{*}{ d.f. } & \multicolumn{2}{|c|}{ Grain yield } & \multicolumn{2}{|c|}{ Darkening } & \multicolumn{2}{|c|}{ Architecture } & \multicolumn{2}{|c|}{ 100-grain weight } \\
\hline & & MS & $\mathrm{P}$ & MS & $\mathrm{P}$ & MS & $\mathrm{P}$ & MS & $\mathrm{P}$ \\
\hline Block/Environment & 5 & $2,131,367$ & 0.0001 & 2.115 & 0.0000 & 0.721 & 0.0190 & 9.305 & 0.0000 \\
\hline Environment (E) & 2 & $1,536,127,151$ & 0.0000 & 4.371 & 0.1715 & 39.194 & 0.0000 & 1746.527 & 0.0000 \\
\hline Treatment (T) & 224 & $1,207,045$ & 0.0000 & 6.363 & 0.0000 & 1.391 & 0.0000 & 26.957 & 0.0000 \\
\hline Lines of Pop(s). ( $\left.\mathrm{L}_{0}\right)$ & 219 & $1,210,638$ & 0.0000 & 6.907 & 0.0000 & 1.348 & 0.0000 & 27.474 & 0.0000 \\
\hline Lines of Pop. $1\left(\mathrm{~L}_{1}\right)^{1}$ & 54 & $1,036,365$ & 0.0000 & 6.302 & 0.0000 & 1.833 & 0.0000 & 27.492 & 0.0000 \\
\hline Lines of Pop. $2\left(\mathrm{~L}_{2}\right)^{2}$ & 53 & 989,346 & 0.0000 & 5.908 & 0.0000 & 1.204 & 0.0000 & 39.646 & 0.0000 \\
\hline Lines of Pop. $3\left(\mathrm{~L}_{3}\right)^{3}$ & 54 & $1,013,218$ & 0.0000 & 8.147 & 0.0000 & 1.227 & 0.0000 & 17.912 & 0.0000 \\
\hline Lines of Pop. $4\left(\mathrm{~L}_{4}\right)^{4}$ & 55 & $1,518,545$ & 0.0000 & 7.947 & 0.0000 & 0.947 & 0.0000 & 22.165 & 0.0000 \\
\hline Population & 3 & $6,165,648$ & 0.0000 & 3.251 & 0.0000 & 4.735 & 0.0000 & 81.569 & 0.0000 \\
\hline Parents (P) & 4 & 559,429 & 0.2277 & 11.063 & 0.0000 & 1.091 & 0.0026 & 3.835 & 0.0497 \\
\hline $\mathrm{L}_{0} v s \mathrm{P}$ & 1 & $3,010,685$ & 0.0059 & 0.872 & 0.0729 & 11.932 & 0.0000 & 6.128 & 0.0515 \\
\hline $\mathrm{T} \times \mathrm{E}$ & 448 & 658,982 & 0.0000 & 0.514 & 0.0000 & 0.367 & 0.0000 & 3.239 & 0.0000 \\
\hline $\mathrm{L}_{0} \times \mathrm{E}$ & 438 & 664,816 & 0.0000 & 0.518 & 0.0000 & 0.361 & 0.0000 & 3.285 & 0.0000 \\
\hline $\mathrm{L}_{1} \times \mathrm{E}$ & 108 & 553,712 & 0.0062 & 0.334 & 0.0599 & 0.382 & 0.0033 & 2.207 & 0.0097 \\
\hline $\mathrm{L}_{2} \times \mathrm{E}$ & 106 & 645,662 & 0.0001 & 0.567 & 0.0000 & 0.341 & 0.0335 & 3.219 & 0.0000 \\
\hline $\mathrm{L}_{3} \times \mathrm{E}$ & 108 & 711,853 & 0.0000 & 0.569 & 0.0000 & 0.312 & 0.1175 & 4.069 & 0.0000 \\
\hline L4 $\times$ E & 110 & 705,902 & 0.0000 & 0.568 & 0.0000 & 0.285 & 0.2967 & 3.656 & 0.0000 \\
\hline Population $\mathrm{x}$ E & 6 & $1,403,171$ & 0.0018 & 1.679 & 0.0000 & 3.712 & 0.0000 & 5.002 & 0.0051 \\
\hline $\mathrm{P} \times \mathrm{E}$ & 8 & 453,019 & 0.5958 & 0.185 & 0.7054 & 0.535 & 0.0418 & 1.213 & 0.6453 \\
\hline$\left(\mathrm{L}_{0} v s \mathrm{P}\right) \times \mathrm{E}$ & 2 & 205,215 & 0.5958 & 0.955 & 0.0297 & 1.046 & 0.0197 & 1.385 & 0.4238 \\
\hline Error & 1120 & 396,091 & & 0.271 & & 0.266 & & 1.612 & \\
\hline Total & 1799 & & & & & & & & \\
\hline CV (\%) & & 17.6 & & 17.7 & & 10.5 & & 5.0 & \\
\hline Mean & & 3582 & & 2.9 & & 4.9 & & 25.3 & \\
\hline Selective accuracy & & 0.82 & & 0.98 & & 0.90 & & 0.97 & \\
\hline
\end{tabular}

'BRSMG Madrepérola x BRS Sublime; ${ }^{2}$ BRSMG Madrepérola x BRS Estilo; ${ }^{3}$ BRSMG Madrepérola x BRS Cometa; ${ }^{4}$ BRSMG Madrepérola x BRS Notável; ${ }^{5} \mathrm{MS}$ : Mean Square.

Mean yield in the experiments was $3582 \mathrm{~kg} / \mathrm{ha}$, a value above the national average registered in this crop season (winter 2012) in Goiás and in the Distrito Federal, which was $2582 \mathrm{~kg} / \mathrm{ha}$ (Feijão, 2015). The mean value of 100-grain weight of the experiments was $25.3 \mathrm{~g}$, near the size desired by the market and the mean value registered for the cultivars BRS Estilo, BRS Cometa, and BRS Notável. For seed-coat darkening, the mean score was 2.9 , which indicates a possibility for selection of lines with light-colored grains (lower than 2.5). The same was observed for plant architecture, with a mean score of 4.9, allowing selection of lines of upright architecture.

The presence of genetic variability among the lines of the populations was confirmed by the estimates of genetic variance and $h^{2}$ (Table 2). For grain yield, the estimates of $h^{2}$ ranged from low to medium (23.4 to $61.7 \%$ ), with an average of $51.7 \%$, values which were similar to those reported in the literature (Pereira et al., 2008; Silva et al., 2009), given that the trait 
is polygenic and highly influenced by the environment (Ramalho et al., 1993). For 100-grain weight, the heritability estimates were high ( $96.8 \%$ on average), ranging from 85.2 to $96.8 \%$. This indicates a large genetic effect and, consequently, ease in selection of lines with bigger grains, aimed at meeting the consumer market demands. This result is in agreement with those previously reported (Melo et al., 2004).

Table 2. Estimates of genetic variance $\left(\sigma_{G}^{2}\right)$, phenotypic variance $\left(\sigma_{F}^{2}\right)$, variance of the lines/population $\mathrm{x}$ environment interaction $\left(\sigma_{G E}^{2}\right)$, and heritability $\left(h^{2}\right)$ for grain yield, seed-coat darkening, plant architecture, and 100 -grain weight, based on combined analysis.

\begin{tabular}{|c|c|c|c|c|c|c|c|c|}
\hline \multirow[t]{2}{*}{ Genotype } & $\sigma_{g}^{2}$ & $\sigma_{f}^{2}$ & $h^{2}$ & $\sigma_{G_{p l}}^{2}$ & $\sigma_{g}^{2}$ & $\sigma_{f}^{2}$ & $h^{2}$ & $\sigma_{G_{p l}}^{2}$ \\
\hline & \multicolumn{4}{|c|}{ Grain yield } & \multicolumn{4}{|c|}{ Seed-coat darkening } \\
\hline Population & 81,122 & 156,935 & 51.7 & 104,562 & 0.778 & 0.895 & 86.9 & 0.096 \\
\hline Pop. $1^{1}$ & 68,350 & 134,344 & 50.9 & 61,333 & 0.650 & 0.817 & 79.6 & 0.025 \\
\hline Pop. $2^{2}$ & 62,732 & 128,249 & 48.9 & 97,109 & 0.674 & 0.766 & 88.0 & 0.115 \\
\hline Pop. $3^{3}$ & 30,753 & 131,343 & 23.4 & 122,864 & 0.904 & 1.056 & 85.6 & 0.116 \\
\hline \multirow[t]{2}{*}{ Pop. $4^{4}$} & 121,443 & 196,848 & 61.7 & 120,549 & 0.911 & 1.030 & 88.4 & 0.116 \\
\hline & \multicolumn{4}{|c|}{ Plant architecture } & \multicolumn{4}{|c|}{100 -grain weight } \\
\hline Population & 0.128 & 0.175 & 72.9 & 0.037 & 3.448 & 3.561 & 96.8 & 0.651 \\
\hline Pop. $1^{1}$ & 0.168 & 0.238 & 70.8 & 0.045 & 3.385 & 3.564 & 95.0 & 0.232 \\
\hline$\overline{\text { Pop. } 2^{2}}$ & 0.139 & 0.156 & 88.9 & 0.029 & 5.049 & 5.139 & 98.2 & 0.625 \\
\hline Pop. $3^{3}$ & 0.119 & 0.159 & 74.9 & 0.018 & 1.978 & 2.322 & 85.2 & 0.956 \\
\hline$\overline{P o p .} 4^{4}$ & 0.091 & 0.123 & 74.1 & 0.007 & 2.672 & 2.873 & 93.0 & 0.795 \\
\hline
\end{tabular}

$\sigma_{g}^{2}$ and $h^{2}$ calculated based on the mean of the covariance estimates between pairs of environments for each trait. ${ }^{1}$ BRSMG Madrepérola x BRS Sublime; ${ }^{2}$ BRSMG Madrepérola x BRS Estilo; ${ }^{3}$ BRSMG Madrepérola x BRS Cometa; ${ }^{4}$ BRSMG Madrepérola x BRS Notável.

The $h^{2}$ estimated for seed-coat darkening and plant architecture can also be considered of high magnitude (on average $86.9 \%$ for darkening of grains and $72.9 \%$ for plant architecture). For seed-coat darkening, the estimates ranged from 79.6 to $88.4 \%$, whereas for plant architecture, the variation ranged from 70.8 to $88.9 \%$ (Table 2). In general, the four populations show promise for generating potential lines since the estimates of $h^{2}$ provide information about the selection potential of the population under study (Vencovsky and Barriga, 1992). For 100-grain weight, darkening of grains, and plant architecture, the high $h^{2}$ estimates reflect greater ease of selection because heritability estimates the reliability of the phenotypic value as an indicator of the reproductive value.

There were differences among the $h^{2}$ estimates and genetic variances considering the lines obtained from different populations. Given that $h^{2}$ is not an immutable property of the trait under study; the study population and the environmental conditions should be taken into consideration (Ramalho et al., 1993). Nevertheless, the results can be considered consistent because they remained high in most of the populations.

The variance of the population by environment interaction for grain yield was 1.3 times greater than the genetic variance of the populations. This suggests that, proportionally, the genotype $\mathrm{x}$ environment interaction is more important for expression of grain yield than for seed-coat darkening, 100-grain weight, and plant architecture, which showed ratios of $0.12,0.19$, and 0.28 , respectively. For these traits, the genotype effect was greater than the interaction effect.

Although the phenotypic correlations of grain yield with 100-grain weight and with darkening rate were positive and significant, both were of low magnitude $(0.29$ and 0.18 , respectively; Table 3). The same was observed for the genetic correlations with these traits 
(0.41 and 0.26, respectively). Araújo et al. (2012) obtained null correlation estimates between yield and darkening of grains, differing in part from the results presented here. As a practical consideration for crop breeding, the nonexistence or low correlation estimates imply that selection of high-yielding lines with light-colored grains is possible.

Table 3. Estimates of phenotypic (F) and genetic (G) correlations between yield, plant architecture, 100-grain weight, and seed-coat darkening for the mean of the environments.

\begin{tabular}{l|c|c|c|c|c|c}
\hline \multirow{2}{*}{ Trait } & \multicolumn{2}{|c|}{ Plant architecture } & \multicolumn{2}{|c|}{100 -grain weight } & \multicolumn{2}{c}{ Darkening } \\
\cline { 2 - 7 } & $r_{F_{x^{\prime} y}}$ & $r_{G_{x^{\prime} y}}$ & $r_{F_{x^{\prime} y}}$ & $r_{G_{x^{\prime} y}}$ & $r_{F_{x^{\prime} y}}$ & $r_{G_{x^{\prime} y}}$ \\
\hline Grain yield & $-0.04^{\mathrm{ns}}$ & $-0.05^{\mathrm{ns}}$ & $0.29^{* *}$ & $0.42^{*}$ & $0.18^{* *}$ & $0.26^{*}$ \\
\hline Plant architecture & - & - & $-0.08^{\mathrm{ns}}$ & $-0.11^{\mathrm{ns}}$ & $-0.32^{* *}$ & $-0.39^{* *}$ \\
\hline 100-grain weight & - & - & - & - & $0.34^{* *}$ & $0.36^{* *}$ \\
\hline
\end{tabular}

${ }^{n s}$ Not significant; ${ }^{* * * *}$ significant at 5 and $1 \%$, respectively, based on a $t$-test.

Between plant architecture and grain darkening, negative, significant, and low magnitude values were obtained for the phenotypic and genetic correlations ( -0.32 and -0.39 , respectively). In contrast, between plant architecture and 100-grain weight there was neither a significant phenotypic association $(-0.08)$ nor a genetic association $(-0.11)$. It should be emphasized that, in this study, the variability between the parents for 100-grain weight was small, with a mean value of $25.3 \mathrm{~g}$ for BRSMG Madrepérola and ranging between 24.8 (BRS Cometa) and $26.7 \mathrm{~g}$ (BRS Estilo) for the other parents. This may explain the difference compared to the results obtained by Collicchio et al. (1997), who observed a correlation between these traits. Therefore, it is possible to associate upright architecture and slow darkening of grains or upright architecture and large grains in the same genotype. Significant correlations were not observed between plant architecture and yield, which indicates that selection based on plant architecture does not imply yield reduction. In contrast, Silva et al. (2009) obtained positive and significant genetic correlations between these traits in two carioca and black grain type populations.

Another parameter of great importance for evaluating the genetic potential of the lines is the gain expected from selection. In general, the estimates of gain varied a great deal from one environment to another and also between traits (Table 4). For grain yield, based on the combined analysis, the gain was $9.8 \%$, regardless of the population of origin, ranging from $4.1 \%$ in the BRSMG Madrepérola x BRS Cometa population to $13.4 \%$ for BRSMG Madrepérola x BRS Notável. Pereira et al. (2008) obtained even greater gain estimates from selection for yield, ranging from 14.5 to $52.2 \%$, also considering the selection of families based on the mean values of combined analysis. However, Pereira et al. (2008) used a selection intensity of $10 \%$, compared to the $20 \%$ used in this study. The number of lines identified among the 44 best indicated the BRSMG Madrepérola x BRS Estilo and BRSMG Madrepérola x BRS Notável populations as the most promising for this trait because they generated 16 and 17 superior lines, respectively.

For 100 -grain weight, the gains ranged from 7.8 to $12.5 \%$ among the populations, and $11.0 \%$ overall (Table 3). The BRSMG Madrepérola x BRS Estilo population stood out, with the greatest number of lines selected (16). The gains estimated for plant architecture and seed-coat darkening were negative because the objective was reduction of the mean value for both traits. For plant architecture, the gain regardless of population of origin was $-9.8 \%$, ranging from -7.6 to $-12.5 \%$ among the populations. The BRSMG Madrepérola x BRS

Genetics and Molecular Research 15 (4): gmr15049081 
Sublime population provided the greatest number of lines among the 44 best (15). In general, based on selection made regardless of the population of origin, the gains estimated for plant architecture, 100-grain weight, and grain yield were approximately $10 \%$.

Table 4. Mean value of the selected lines, gain expected from direct and simultaneous selection (GS, \%), and number of lines selected from each population (in parentheses), among the 44 overall best for grain yield, plant architecture, 100-grain weight, and seed-coat darkening, based on combined analysis of the environments.

\begin{tabular}{|c|c|c|c|c|}
\hline \multirow[t]{3}{*}{ Genotype } & \multicolumn{2}{|c|}{ Direct selection } & \multicolumn{2}{|c|}{ Simultaneous selection* } \\
\hline & \multicolumn{4}{|c|}{ Grain yield $(\mathrm{kg} / \mathrm{ha})$} \\
\hline & Mean & GS & Mean & GS \\
\hline Population & 4119 & $9.8(44)$ & 3,578 & $1.7(44)$ \\
\hline BRSMG Madrepérola x BRS Sublime & 3985 & $7.7(06)$ & 3,591 & $1.9(10)$ \\
\hline BRSMG Madrepérola x BRS Estilo & 4273 & $8.7(17)$ & 3,682 & $0.8(12)$ \\
\hline BRSMG Madrepérola x BRS Cometa & 3892 & $4.1(05)$ & 3,381 & $0.5(13)$ \\
\hline \multirow[t]{2}{*}{ BRSMG Madrepérola x BRS Notável } & 4207 & $13.4(16)$ & 3,706 & $4.5(09)$ \\
\hline & \multicolumn{4}{|c|}{ Plant architecture (1-9) } \\
\hline Population & 4.2 & $-9.8(44)$ & 5.0 & 1.5 \\
\hline BRSMG Madrepérola x BRS Sublime & 4.1 & $-10.2(15)$ & 5.0 & 3.0 \\
\hline BRSMG Madrepérola $x$ BRS Estilo & 4.2 & $-12.5(12)$ & 5.2 & 5.3 \\
\hline BRSMG Madrepérola x BRS Cometa & 4.3 & $-9.4(12)$ & 4.9 & 0.2 \\
\hline \multirow[t]{2}{*}{ BRSMG Madrepérola x BRS Notável } & 4.5 & $-7.6(05)$ & 4.9 & -1.6 \\
\hline & \multicolumn{4}{|c|}{ 100-grain weight $(\mathrm{g})$} \\
\hline Population & 28.1 & $11.0(44)$ & 24.8 & -1.4 \\
\hline BRSMG Madrepérola $x$ BRS Sublime & 27.5 & $10.5(10)$ & 24.3 & -1.8 \\
\hline BRSMG Madrepérola $x$ BRS Estilo & 29.1 & $12.5(16)$ & 24.9 & -3.5 \\
\hline BRSMG Madrepérola x BRS Cometa & 27.3 & $7.8(07)$ & 25.2 & 0.9 \\
\hline \multirow[t]{2}{*}{ BRSMG Madrepérola x BRS Notável } & 27.7 & $9.4(11)$ & 24.7 & -1.7 \\
\hline & \multicolumn{4}{|c|}{ Seed-coat darkening (1-5) } \\
\hline Population & 1.5 & $-41.2(44)$ & 1.7 & -35.9 \\
\hline BRSMG Madrepérola x BRS Sublime & 1.4 & $-38.9(13)$ & 1.6 & -33.4 \\
\hline BRSMG Madrepérola $x$ BRS Estilo & 1.5 & $-42.6(09)$ & 1.6 & -40.0 \\
\hline BRSMG Madrepérola x BRS Cometa & 1.7 & $-37.6(12)$ & 1.9 & -31.6 \\
\hline BRSMG Madrepérola x BRS Notável & 1.6 & $-42.0(10)$ & 1.7 & -36.8 \\
\hline
\end{tabular}

*Multiplicative "weight-free and parameter-free" selection index. Positive and negative values refer to an increase and decrease, respectively, in the mean value of the trait.

For seed-coat darkening, the gains obtained were much greater, at $-41.2 \%$, based on selection regardless of population of origin, with little variation among the populations $(-37.6$ to $-42.6 \%)$. This fact can be explained by the type of genetic control of this trait, which is mono- or oligogenic (Junk-Knievel et al., 2008; Elsadr et al., 2011; Silva et al., 2008; 2014). In addition, gains from selection for seed-coat darkening varied little among the populations and environments. All populations contributed with a similar number of lines among the 44 best. This result is of great importance because, although a genotype $x$ environment interaction was detected for darkening of grains, selection based on evaluation of only one environment can generate satisfactory gains for this trait.

Simultaneous selection of traits proposed by the multiplicative "weight-free and parameter-free" index, considering the criteria of yield above the general average and a score lower than 2.5 for darkening of grains, based on combined analysis, showed gains for yield $(1.7 \%)$ and seed-coat darkening (-35.9\%) (Table 4), as expected. For 100-grain weight and plant architecture, this combined selection, for grain yield and darkening of grains, resulted in a decline of 1.4 and $1.5 \%$ in the overall mean, respectively. For seed-coat darkening, selection was more effective, with a gain of $35.9 \%$, which can be explained by the criteria of selection having been more rigorous for darkening of grains.

Genetics and Molecular Research 15 (4): gmr15049081 
Considering the simultaneous selection practiced on the mean of the three environments, the four populations generated a similar number of lines among the 44 best, which suggests that all populations have the potential for generation of superior lines. The BRSMG Madrepérola x BRS Cometa and BRSMG Madrepérola x BRS Estilo populations generated 13 and 12 superior lines, respectively (Table 4). Considering the number of lines selected in each population, in each environment, the number of lines among the best 44 was similar to the mean of the three environments.

Direct selection revealed the greatest individual gains for the traits, but with a reduced practical effect since the lines must show favorable performance for various traits to be recommended as new cultivars. For that reason, use of the selection index proved to be efficient since it allowed gains from selection for both yield and darkening of grains, which can increase the possibility of obtaining lines with high potential for indication as new cultivars. New cultivars must possess the various agronomic, industrial, and commercial characteristics required by the different segments of the common bean production chain.

To conclude, the estimates of $h^{2}$, genetic variance, and gain expected from selection were high, indicating the possibility of successful selection for slow seed-coat darkening, high yield potential, large grains, and upright plant architecture in all evaluated populations. There was no strong genetic association among grain yield, 100-grain weight, seed-coat darkening, and plant architecture in common bean. Considering simultaneous selection, it was not possible to obtain high genetic gains for all four traits combined. Forty-four elite lines that combined high yield, more upright plant architecture, slow seed-coat darkening, and commercial size were selected.

\section{Conflicts of interest}

The authors declare no conflict of interest.

\section{ACKNOWLEDGMENTS}

We thank Embrapa Arroz e Feijão, Embrapa Produtos e Mercados - Brasília Office and Universidade Federal de Goiás for funding and support in carrying out this study. The CNPq funded the study and granted doctorate scholarships to R.C. Alvares and F.C. Silva as well as fellowships of technological development and innovative extension to P.G.S. Melo L.C. Melo, and H.S. Pereira.

\section{REFERENCES}

Araújo LCA, Ramalho MAP and Abreu AFB (2012). Estimates of genetic parameters of late seed-coat darkening of carioca type dry beans. Cienc. Agrotec. 36: 156-162. http://dx.doi.org/10.1590/S1413-70542012000200003

Carneiro JES, Abreu AFB, Ramalho MAP, Paula Júnior TJ, et al. (2012). BRSMG Madrepérola: common bean cultivar with late-darkening carioca grain. Crop Breed. Appl. Biotechnol. 12: 281-284. http://dx.doi.org/10.1590/S198470332012000400008

Collicchio E, Ramalho MAP and Abreu AFB (1997). Associação entre o porte da planta do feijoeiro e tamanho dos grãos. Pesqui. Agropecu. Bras. 32: 297-304.

Couto KR, Santos JB, Ramalho MAP and Silva GS (2010). Identificação de marcadores microssatélites relacionados ao escurecimento de grãos em feijão. Pesqui. Agropecu. Bras. 45: 1068-1074. http://dx.doi.org/10.1590/S0100204X2010001100006

Cruz CD (2013). Genes - a software package for analysis in experimental statistics and quantitative genetics. Acta Scientiarum 35: 271-276.

Genetics and Molecular Research 15 (4): gmr15049081 
Elsadr HT, Wright LC, Pauls KP and Bett KE (2011). Characterization of seed coat post harvest darkening in common bean (Phaseolus vulgaris L.). Theor. Appl. Genet. 123: 1467-1472. http://dx.doi.org/10.1007/s00122-011-1683-8

Elston RC (1963). A weight-free index for the purpose of ranking or selection with respect to several traits at a time. Biometrics 19: 85-97. http://dx.doi.org/10.2307/2527573

FAO (2016). Faostat. http://faostat.fao.org/site/567/DesktopDefault.aspx?PageID=567. Accessed May 10, 2011.

Faria LC, Melo PGS, Pereira HS, Del Peloso MJ, et al. (2013). Genetic progress during 22 years of improvement of carioca-type common bean in Brazil. Field Crops Res. 142: 68-74. http://dx.doi.org/10.1016/j.fcr.2012.11.016

Feijão (2015). Dados conjunturais do feijão - Brasil - 1985 a 2011. http://www.cnpaf.embrapa.br/socioeconomia/index. $\mathrm{htm}$. Accessed January 2, 2013.

Junk-Knievel DC, Vandenberg A and Bett KE (2007). An accelerated postharvest seed-coat darkening protocol for pinto beans grown across different environments. Crop Sci. 47: 694-702. http://dx.doi.org/10.2135/cropsci2006.05.0325

Junk-Knievel DC, Vandenberg A and Bett KE (2008). Slow darkening in pinto bean (Phaseolus vulgaris L.) seed coats is controlled by a single major gene. Crop Sci. 48: 189-193. http://dx.doi.org/10.2135/cropsci2007.04.0227

Martins SM, Melo PG, Faria LC, Souza TL, et al. (2016). Genetic parameters and breeding strategies for high levels of iron and zinc in Phaseolus vulgaris L. Genet. Mol. Res. 15: http://dx.doi.org/10.4238/gmr.15028011.

Melo LC (2009). Procedimentos para condução de experimentos de Valor de Cultivo e Uso em feijoeiro comum. Embrapa Arroz e Feijão, Santo Antônio de Goiás.

Melo LC, Santos JB and Ferreira DF (2004). QTL mapping for common bean grain yield in different environments. Crop Breed. Appl. Biotechnol. 4: 135-144.

Moura MM, Carneiro PCS, Carneiro JES and Cruz CD (2013). Potencial de caracteres na avaliação da arquitetura de plantas de feijão. Pesqui. Agropecu. Bras. 48: 417-425. http://dx.doi.org/10.1590/S0100-204X2013000400010

Pereira HS, Santos JB, Souza TP and Lima IA (2008). Seleção fenotípica e assistida por marcadores moleculares de famílias de feijoeiro-comum com alta produtividade. Pesqui. Agropecu. Bras. 43: 1551-1558. http://dx.doi. org $/ 10.1590 / \mathrm{S} 0100-204 \mathrm{X} 2008001100014$

Pereira HS, Almeida VM, Melo LC, Wendland A, et al. (2012). Influência do ambiente em cultivares de feijoeiro-comum em cerrado com baixa altitude. Bragantia 71: 165-172. http://dx.doi.org/10.1590/S0006-87052012005000024

Ramalho MAP, Santos JB and Zimmerman MJO (1993). Genética quantitativa em plantas autógamas: aplicações ao melhoramento do feijoeiro. Universidade Federal de Goiás, Goiânia.

Ramalho MAP, Santos JB, Abreu AFB and Nunes JAR (2012) Aplicações da genética quantitativa no melhoramento de plantas autógamas. Editora UFLA, Lavras

Resende MDV and Duarte JB (2007). Precisão e controle de qualidade em experimentos de avaliação de cultivares. Pesqui. Agropecu. Trop. 37: 182-194.

Ribeiro ND, Jost E and Cargnellutti Filho A (2004). Efeitos da interação genótipo x ambiente no ciclo e na coloração do tegumento dos grãos do feijoeiro comum. Bragantia 63: 373-380. http://dx.doi.org/10.1590/S0006$\underline{87052004000300007}$

SAS institute Statistical analysis system (2008). SAS/STAT 9.2 Users's guide. Version 9.2, Cary, NC. SAS Institute Inc., Cary.

Siqueira BS, Pereira WJ, Batista K, Oomah BD, et al. (2014). Influence of storage on darkening and hardening of slowand regular-darkening carioca bean (Phaseolus vulgaris L.) genotypes. J. Agric. Stud. 2: 87-104. http://dx.doi. org/10.5296/jas.v2i 2.5859

Silva CA, Abreu AFB and Ramalho MAP (2009). Associação entre arquitetura de planta e produtividade de grãos em progênies de feijoeiro de porte ereto e prostrado. Pesqui. Agropecu. Bras. 44: 1647-1652. http://dx.doi.org/10.1590/ $\underline{\text { S0100-204X2009001200013 }}$

Silva FC (2012). Potencial genético de populações segregantes de feijoeiro-comum para escurecimento e cocção dos grãos. Master degree thesis, Universidade Federal de Goiás, Goiânia.

Silva FC, Melo PGS, Pereira HS and Melo LC (2014). Genetic control and estimation of genetic parameters for seed-coat darkening of carioca beans. Genet. Mol. Res. 13: 6486-6496. http://dx.doi.org/10.4238/2014.August.25.12

Silva GS, Ramalho MAP, Abreu AFB and Silva FB (2008). Genetic control of early grain darkening of carioca common bean. Crop Breed. Appl. Biotechnol. 8: 299-304. http://dx.doi.org/10.12702/1984-7033.v08n04a07

Vencovsky R and Barriga P (1992). Genética biométrica no fitomelhoramento. Sociedade Brasileira de Genética, Ribeirão Preto.

Genetics and Molecular Research 15 (4): gmr15049081 